\title{
Measuring The Social Rate Of Return In Public Sector Labor Markets
}

\author{
Anthony Stokes, Australian Catholic University, Australia
}

Sarah Wright, Australian Catholic University, Australia

\begin{abstract}
In many public sector labor markets, employee earnings do not reflect the value of that occupation to society. This paper provides some alternative models to measure that value.
\end{abstract}

\section{INTRODUCTION}

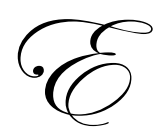

ducation authorities around the world need to consider the level of support that they will give to students undertaking higher education. It is argued by Rizzo (2005) that in the market of higher education there is a need for Government funding to ensure that a socially optimal level of higher education is consumed. Under a 'user pays' system individuals will under invest in higher education as they will not recognise the externalities society receives from workers with a university education. The benefits of education are unquestionable but difficult to quantify. Marshall (1890) in Principles of Economics states:

All that is spent during many years in opening the means of higher education to the masses would be well paid for if it called out one more Newton or Darwin, Shakespeare or Beethoven (p.216).

It is argued by Rizzo (2005) that extra Government funding is justified if the Social Rate of Return (SRR) to higher education is both positive and greater than the return on alternative public investments. Topel (2005) highlights the importance of a comparison between the Private and Social Rates of Return to higher education. He argues that if the SRR is greater than the Private Rate of Return (PRR) to a university degree than there is an underinvestment of Government funding.

Norris (2000) states that the SRR differs from the PRR as costs include the opportunity cost to society or loss of output, while an individual continues further study (measured by pre-tax earnings), and direct costs such as operating expenses. The benefits received by society are measured by the pre-tax earnings differential, that is, the increase in marginal productivity derived from higher education. A limitation of the PRR model is that it measures the market value on the return on education. Psacharopoulos and Pastrinos (2002 p.2) argue that the PRR model cannot measure the return for public sector employment as public sector wages do not reflect market wages. Hence the earnings do not reflect the social benefits or the private economic efficient outcomes.

This paper will provide some possible methodologies to produce a measurement of the SRR for public sector employment that more accurately reflects the market value of the graduate employee. This will then allow for a more accurate comparison to be made between the PRR and SRR of those graduates and the level of support the government should provide those occupations.

\section{THE PUBLIC SECTOR LABOR MARKET}

There are particular graduate labor markets such as those for nurses and teachers that tend to be dominated by public sector employers. These labor markets are not competitive markets but rather monopsonistic markets. The wage levels do not reflect the marginal productivity of the workers. 
The standard model of labor demand in economics is the neoclassical marginal productivity theory of demand (Kaufman and Hotchkiss 2000, Norris 2000, McConnell 2003). The greater the marginal productivity of labor, then the higher the demand there would be for that labor, and as a result the higher the relative wage rate. However, as Zabalza (1979) points out, there are several reasons why such an analysis is inadequate. First, the marginal productivity theory of wages would have to be applied differently to the teacher labor market as it is difficult, if not almost impossible, to measure the productivity of a teacher. Second, the dominance of the public sector makes the education department a near monopsonistic buyer of teachers' labor. In such an environment the quantity of labor demanded at a particular wage rate is strongly influenced by the policy makers in the education department and the government. Zabalza (1979 p.17) states that 'the allocation of resources will have already been made on the basis of political considerations, and the number of teachers demanded will then constitute a datum of the problem rather than something subject to economic analysis.' As a result the number of teachers that will be demanded will really be determined by the amount of money that education authorities are willing to spend on employing teachers at the existing teacher wage rates. In addition policy makers determine desired pupil-teacher ratios and staffing formulas for the schools. As a result, the three independent variables in the analysis of demand for teachers (Zabalza 1979) become:

- $\quad$ the number of pupils to be educated and the desired pupil teacher ratio,

- $\quad$ the amount of money education authorities are willing to spend on teacher salaries, and

- $\quad$ the average level of salaries per teacher.

A similar comparison to Zabalza's could also be made for nurses and doctors in public hospitals. While the monopsonistic power of the public sector employer of nurses and teachers may not be an issue in US labor markets (Boal and Ransom 2000, Hirsch and Schumacher 1995), it is a common feature in many other nations including England and Australia (Nowak 2000, Nowak and Preston 2000, Stokes 2005).

Figure 1: Shortages in the labor market for teachers

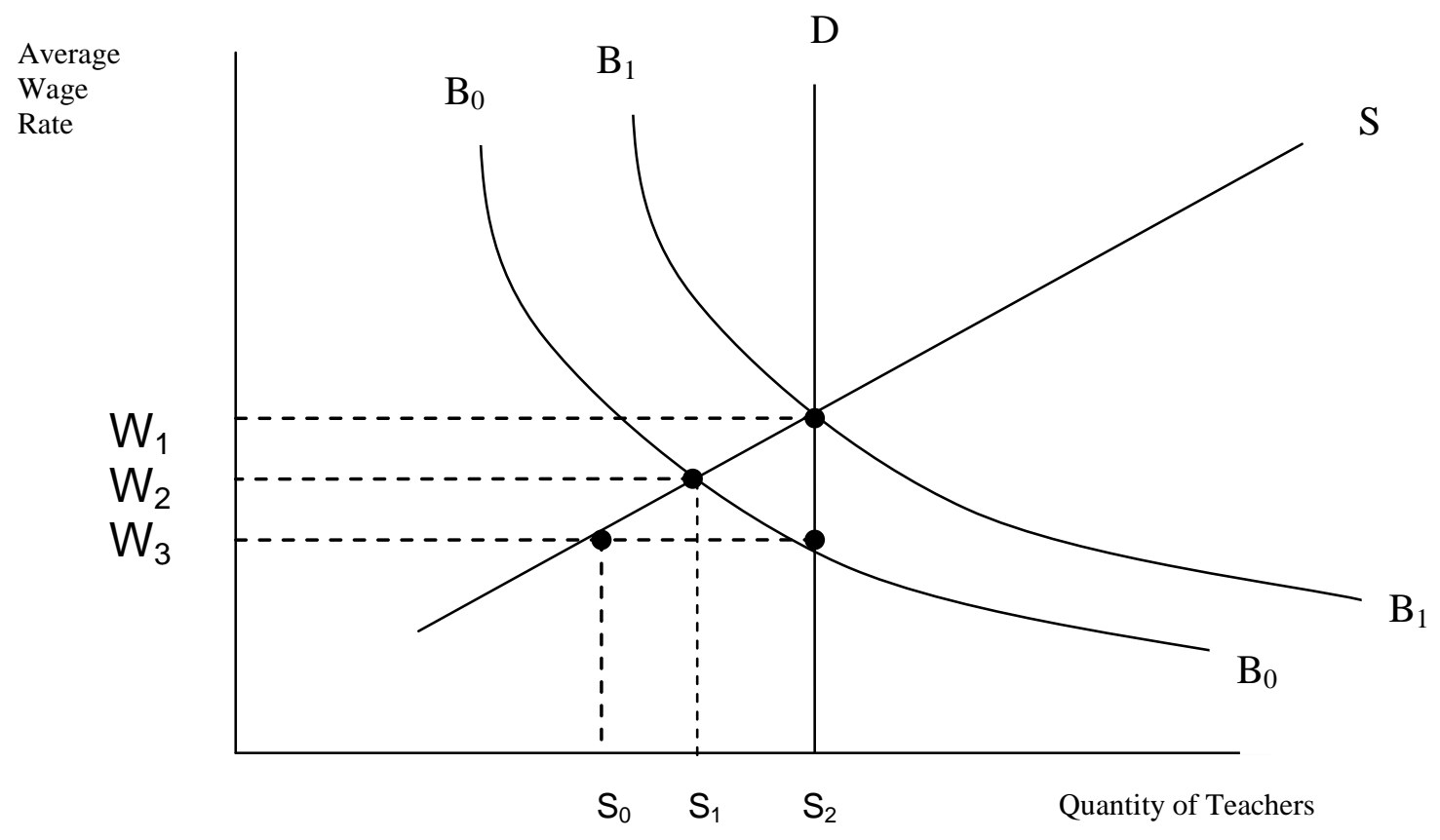


Figure $1^{1}$ demonstrates the effect of a monopsonistic employer. Average wages (W) are on the vertical axis and the number of teachers (S) on the horizontal axis. SS is a linear representation of the supply function. The vertical line $\mathrm{D}$ shows the demand for teachers based on a given desired pupil- teacher ratio. The curve BB represents the demand relationship given a particular financial budget constraint. Each of the BB curves in Figure 1 represents different ways of spending the budget. If the budget constraint is $\mathrm{B}_{0} \mathrm{~B}_{0}$ and the average wage is $\mathrm{W}_{3}$, this wage will produce a supply of $S_{0}$. This supply will not use up the full budget allocation and will create a teacher shortage as demand is $S_{2}$ and the supply at wage, $W_{3}$, is only $S_{0}$. If the wage rate is moved up to $\mathrm{W} 2$, by using up the allocated budget, there will be an increase in the supply of teachers to $S_{1}$ but a teacher shortage would still exist, the gap $S_{1} S_{2}$. Only by increasing the budget constraint to $B_{1} B_{1}$ and increasing the wage rate to $W_{1}$ would the demand and supply of teachers achieve equilibrium.

In this market situation it is also possible that wages will be set in excess of market equilibrium where demand for teachers equals the supply of teachers. In Figure 2, the wage rate is fixed at $\mathrm{W}_{4}$. At this wage rate, $\mathrm{S}_{4}$ qualifies people would like to become teachers. Education authorities would like to employ $S_{3}$ teachers to meet the desired pupil-teacher ratio. However, given the budget constraint $\mathrm{B}_{0} \mathrm{~B}_{0}$, only $\mathrm{S}_{1}$ teachers would be employed leading to a gap of $S_{1} S_{4}$ unemployed, surplus, teachers. If wages were flexible and given the budget constraint, $S_{2}$ teachers would be employed but now there would actually be a shortage of teachers, the gap $S_{2} S_{3}$.

The monopsonist determines the demand in the market and as a result can influence the wage rate. Rather than being a price taker, as occurs in a competitive market and facing a horizontal labor supply curve, the monopsonist faces an upward sloping labor supply curve. Due to budget constraints many public sector markets face the situation in Figure 1. The monopsonist may thus face a shortage of labor at budget constrained wage rate, but as McConnell, Brue and Macpherson (2003) point out, the monopsonist's self interest may keep it from raising wages above $\mathrm{W}_{3}$. They consider that "this may explain why monopsony markets are characterized by chronically unfilled job vacancies" (183). Labor is under-allocated to the provision of goods and services produced in monopsonised industries. This is particularly reflected in shortages of teachers and nurses in Australia (Nowak 2000, Nowak and Preston 2000, Stokes 2005)

Figure 2: Surplus in the labor market for teachers

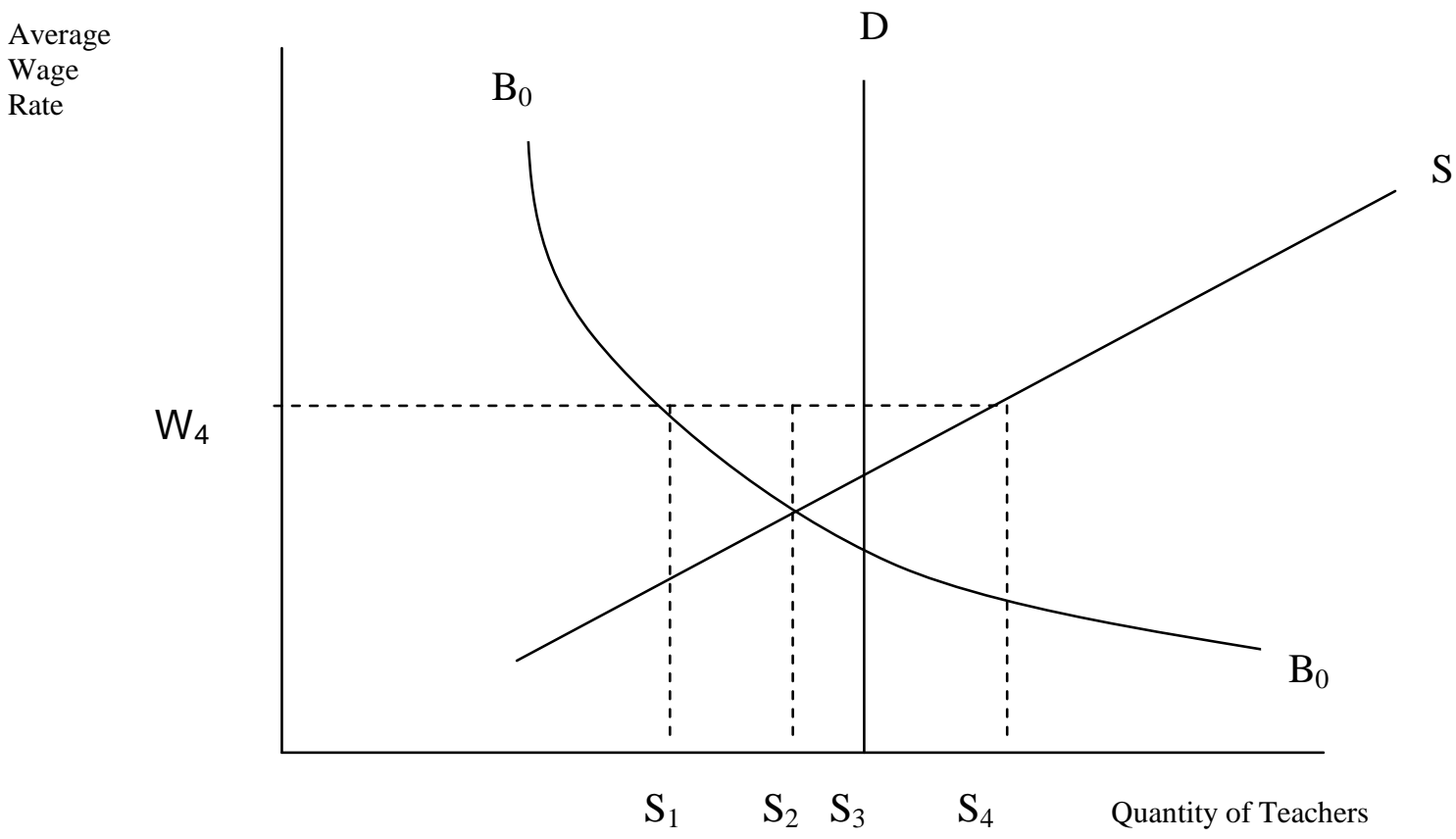

\footnotetext{
${ }^{1}$ Figure 1 is based on Zabalza 1979.
} 


\section{DIFFICULTIES WITH MEASURING THE SRR}

The benefits to society from higher education extend beyond the private benefits the individual receives to include the externalities or spillover benefits of higher education. These include the non-pecuniary benefits to the individual (greater job security, consumption benefits and better health) and the non-pecuniary benefits to society (lower crime rates, higher productivity and democratisation). McMahon (2004 p. 211) states 'the size of these externalities which include education's impacts on development goals are the main rationale on efficiency grounds for government support of education'. However, most conventional estimates of the Social Rate of Return (SRR) do not take into account these non-monetary externalities, as they are difficult to measure. While the OECD (2004) report that the SRR to higher education throughout the world is both positive and sizeable, according to Rizzo (2005), these social returns represent the lower bound return for society's investment in higher education. Rizzo (2005) points out that the SRR does not account for all the benefits that accrue to society from public spending on higher education.

Rizzo (2005) also argues that another reason why the SRR measures only the minimum return to society is the difficulty with quantifying the non-pecuniary benefits of higher education. A significant non-pecuniary benefit to both the individual and society that is ignored when measuring the SRR to higher education is consumption. For example, university students enjoy both classes and the social activities available on the campus and society enjoys participating in special lectures, athletics programs and using campus facilities. Villiers an Nieuwoudt (2005) suggest that the non-pecuniary benefits to individuals with university degrees extend further to include better communication, more law abiding behaviour, and a greater contribution to the intellectual and cultural well being of the community. These benefits are non-excludible and suggest that to some degree higher education is a public good.

Baum and Payea (2004) suggest there are other non-pecuniary benefits that accrue to society from graduates with university degrees. These include:

- $\quad$ lower levels of unemployment and poverty;

- $\quad$ greater job security;

- $\quad$ a lower dependence on welfare and social programs;

- $\quad$ lower smoking rates;

- $\quad$ lower incarceration rates.

Baum and Payea (2004) also argue that university graduates are more likely to vote, donate blood and carry out volunteer work and are more likely to have children with higher cognitive skill levels. This is supported by the study of Haveman and Wolfe (1984) that found a child's level of education and cognitive ability were positively related to their mother's and father's level of education.

Two further benefits that the individual receives from a university education, which are increasingly important today, are referred to as the 'opportunity option' and 'technology hedge'. The 'opportunity option' refers to the wider employment opportunities that avail to a university graduate compared to a high school graduate. Rizzo (2005) argues this benefit is of increasing value to university graduates given the ability for labor markets to change and jobs to relocate overseas. The 'technology hedge' refers to the ability of an individual to adapt to technological changes. Rizzo (2005) argues the more educated a worker is the more likely they are to adapt to technological changes in the workplace. However, an individual's ability to adapt to new technology is not only a benefit to the individual but also a benefit to society. Society benefits from a person's ability to both adapt, discover and use new ideas and technology.

It could therefore be argued that the SRR to education measures only the pecuniary benefits to society. However, according to Weisbrod (1962) there is a significant pecuniary benefit that is ignored in the SRR to education, named by Weisbrod as the 'financial option'. Weisbrod (1962 p.108) states the financial option is 'the value of the opportunity to obtain still further education'. Weisbrod (1962) argues that a high achieving student is not only more likely to receive a higher income but a higher achieving student has the option of further education. 
Weisbrod (1962) argues that students are unaware of these options at the time of making their decisions therefore the Government should invest in higher education to avoid systematic under-investments.

Rizzo (2005) agrees that, if the financing of higher education was left to private individuals, there is the likelihood that they would choose suboptimal levels of education from the viewpoint of society. Rizzo (2005 p.38) states:

Even if the entire Social Rate of Return is comprised of the private return, if private agents systematically underinvest due to their inability to recognise the private benefits, some Government investment is justified.

Furthermore, studies measuring the effects of human capital on economic growth suggest there are positive externalities of higher education that are generally ignored in measuring the SRR to higher education. According to the study by Mingat and Tan (1996), increasing investment in higher education in high income countries by one percentage point delivers a return to society of 20 percent. This return is twice as great as conventional estimates, therefore suggesting that conventional measurements of SRR measure only the lower bound returns to society.

According to the Australia Treasury (2006), if the level of education of Australia's workforce increased 0.15 years, then Australia's productivity would increase 0.62 percent, Australia's workforce participation would increase 0.48 percent and Australia's economic growth 1.1 percent by the year 2040.

While most economists agree that there are public benefits from higher education, economists disagree on the size of these externalities. While researches have attempted to measure some non-market effects of education, only McMahon (2004) has attempted to measure the total value of education externalities from education. The total Social Rates of Return to education are based on cross country data from 78 countries over 40 years. McMahon (2004) considers the following externalities in his study:

- $\quad$ better public health and lower net population rates;

- democratization, human rights and political stability;

- lower crime rates;

- deforestation;

- $\quad$ water pollution and air pollution;

- $\quad$ poverty reduction and inequality reduction;

- $\quad$ geographic spillovers;

- $\quad$ informal knowledge dissemination.

Table 1 shows the total SRR to higher education for different regions of the world. The total SRR is the sum of the monetary Social Rate of Return, non market private returns and non market education externalities. The non market private returns are the benefits that both the individual and their family receive from higher education which are separate to the above listed externalities. These include better individual and family health, longevity, cognitive development of children and consumption benefits. The non market education externalities refer to the above list of externalities.

Table 1: The total Social Rates of Return to higher education

\begin{tabular}{lcccc}
\hline Region of the world & $\begin{array}{c}\text { Monetary Social Rate } \\
\text { of Return }\end{array}$ & $\begin{array}{c}\text { Non market private } \\
\text { returns }\end{array}$ & $\begin{array}{c}\text { Non market } \\
\text { education } \\
\text { externalities }\end{array}$ & $\begin{array}{c}\text { Total Social Rate of } \\
\text { Return }\end{array}$ \\
\hline Africa & 11.3 & 9.0 & 4.0 & 24.3 \\
Latin America & 12.3 & 9.8 & 4.0 & 26.1 \\
Asia & 11.0 & 8.8 & 3.4 & 23.2 \\
OECD & 8.5 & 6.8 & 2.5 & 17.8 \\
\hline
\end{tabular}

Source: Modified from McMahon (2004) 
The results show that monetary or conventional SRR measurements underestimate the benefits society receives from higher education. For example, the monetary Social Rate of Return is less than half the total Social Rate of Return for OECD nations. The gap is even wider in less developed regions, suggesting a greater benefit of education to society in these regions.

\section{MODELS FOR MEASURING THE MONETARY SRR}

While the authors accept the issues of measurement discussed above, this paper is going to consider possible methodologies for measuring the monetary value of the SRR. By doing so we are providing a minimum economic measurement of the value to society of higher education. This study specifically measures the social rates of return for economic teachers in Australia. The methodology used in this study could be adapted for other public sector occupations in different countries.

In Australia the teacher labor market is not a properly functioning competitive market. The Government is a near monopolistic supplier of schooling and a near monopsonistic buyer of teachers (Zabalza, Turnbull and Williams 1979, Stokes 2005). According to Stokes (2005) and the Productivity Commission (2007) there is already a shortage of maths and science teachers and in the next few years this shortage will extend to other areas of teaching. The Productivity Commission (2007), Cull (2007) and Stokes (2005) have supported wider claims that the shortage of teachers is partly a result of the inflexible nature of teachers pay structures that prevent 'price signals' from communicating the shortage in the teaching profession.

Stokes (2005) states that the New South Wales Department of Education and Training (DET) employs 62.7 percent of all secondary teachers in New South Wales. Stokes (2005 p.45) also points out that while the Catholic Education Offices are the second largest purchaser of secondary teachers (employing 21.6 percent of all secondary teachers in NSW) the 'Catholic Education Offices model their wage policies closely on that of DET'. Stokes argues the remainder of non-Governmental schools, which employ 15.7 percent of all secondary teachers in NSW and offer allowances to both attract higher quality staff and reward teachers for their involvement in extra curricular activities, are still influenced by DET wages and reliant on Government funding. So the wage levels for teachers throughout each state are either identical or linked to the Government pay scales.

The Social Rates of Return for economics teachers in this model are compared to those of the occupation economist. The economics teachers would generally have at least a three year degree in the economics discipline, the same as the economist, but would also do a one year post graduate diploma in teaching or education. Therefore the basic three year degree qualifications of each group of graduates are the same.

The base rates of return in this study are calculated following the OECD (2004) approach in Table 2. The Social Rate of Return measures the return to society from both private and public investment in higher education. The measurements in this study allow 20 percent for the innate ability of the university graduate and are thus measured as the 80 percent level reflecting the proportion of the benefit the graduate receives that is due to extra education. The monetary return is the gross wage premium, while the costs to society include both the opportunity cost to the individual and the cost to the Government. The measurement of costs and benefits to society in this study follow the methodology in Table 2 and uses predicted earnings based on data from the Australian Bureau of Statistics (ABS) Household Expenditure Survey (HES) and Survey of Income and Housing (SIH) 2003-04 CURF. (More detail on the methodology to measure the Private and Social Rates of Return are provided in the Appendix) 
Table 2: The OECD method of calculating the social costs and social benefits

Private costs $=$ Forgone earnings + direct private expenditures + increased future taxes

Public costs $=$ Lost tax receipts during the training + public expenditures

Social costs $=$ Private costs + public costs

Private benefits $=$ Increases in earnings + higher probability of being employed

Public benefits $=$ Additional tax receipts

Social benefits $=$ Private benefits + public benefits

Source: Modified from OECD 2004

Psacharopoulos (1975) argues that the PRR will be higher than the SRR when the SRR is calculated this way as the subsidies by the Government towards the cost of higher education are so large that they reduce the $S_{R R}{ }^{2}$. However, the estimates by Borland et al. (2000) and the results in this study show that this is not always the case for higher education in Australia.

Table 3 compares the return to society for both male and female economics teachers for the year 2005 using different SRR models. Model 1 is the original SRR for an economics teacher. It follows the methodology of Figure 3 to measure the gross income of an economics teacher and assumes that the teachers have forgone the income that a year 12 graduate earned while they were studying. Models 2 and 3 assume that the economics teacher is paid the gross income of the economist (as determined in the competitive market) minus the loss of tax revenue as a result of being a teacher, i.e. the difference in the tax paid by an economist and the tax paid by the teacher. Model 2 assumes that the economics teacher forgoes the income of a year 12 graduate for the four years of study, while Model 3 assumes that in the fourth year of study the graduate had forgone the income of an economist. These measurements are minimum estimates of the Social Rates of Return, as it could be expected that an extra year of higher education, training to be a teacher, would further increase the productivity of the economics graduate. There has been no adjustment for the extra benefit to society of the additional year of higher education in these models.

Table 3: A comparison of SRR models for both male and female economics teachers

\begin{tabular}{lcccc}
\hline & $\begin{array}{c}\text { SRR for an economist } \\
(80 \text { percent })\end{array}$ & $\begin{array}{c}\text { Model 1 SRR } \\
(80 \text { percent })\end{array}$ & $\begin{array}{c}\text { Model 2 SRR } \\
(80 \text { percent })\end{array}$ & $\begin{array}{c}\text { Model 3 SRR } \\
(80 \text { percent })\end{array}$ \\
\hline $\begin{array}{c}\text { Male } \\
\text { 2005 }\end{array}$ & 15.13 & 6.89 & 10.00 & 9.02 \\
$\begin{array}{c}\text { Female } \\
2005\end{array}$ & 22.51 & 10.32 & 14.92 & 12.55 \\
\hline
\end{tabular}

\footnotetext{
${ }^{2}$ Psacharopoulos, G. and Pastrinos, H. (2002) measured the PRR and SRR for 98 countries between 1960 and 1997 and found that the PRR for higher education was higher than the SRR for higher education on average at 19.0 percent and 10.8 percent respectively.
} 
The findings show that the original SRR to society for an economics teacher underestimates the return society receives. The SRR for the economics teacher is substantially lower than the return for the graduate working in the occupation of economist. This is primarily due to greater reward the market pays for the occupation of economist as reflected in the higher income of the economist and as a result the higher tax paid to the Government. If it is assumed that the economics teacher had forgone the income of a year 12 graduate while at university then the SRR for 2005 would increase 3.11 percentage points for males and 4.6 percentage points for females. If however, it is assumed that the economics teacher forgoes in their fourth year of study the income of an economist then the SRR for 2005 would increase 2.13 percentage points for males and 2.23 percentage points for females.

This not only suggests that the competitive market values the economist and the skill of the economics teacher greater than the monopsonist employer but that the economics teacher is under funded in the Government's allocation towards higher education. It also helps to explain why there is a shortage of economics teachers in schools (Correy, 2007). Similar comparisons could be made for other teachers eg. IT, maths, science, and for nurses compared to similar professions, such as scientists.

\section{CONCLUSION}

This methodology of comparing the social benefits of graduates in public sector and monopsonistic labor markets to their counterparts in the private sector provides a more accurate measure of their value to society. This is an important consideration in determining the level of Government funding and support in these fields. It is important to note that the monopsonistic nature of the labor markets for teachers and nurses has forced the Australian Government to make these two areas national priorities for funding. Despite this, the Private and Social Rates of Returns in these areas remain low and have resulted in shortages of graduates. The earnings of teachers and nurses do not reflect the competitive market value of their qualifications. If the monopsonistic nature of the labor market for nurses and teachers is taken into consideration then the findings in Tables 4 underestimate the return society receives from teachers and nurses.

Table 4: The PRR and SRR to different occupations for males and females, 2005

\begin{tabular}{lcc}
\hline & PRR (80 percent) & SRR $(80$ percent $)$ \\
\hline Male & 14.20 & 15.13 \\
Economist/financier & 8.62 & 7.58 \\
Nurse & 6.75 & 6.95 \\
Secondary teacher- humanities & 6.37 & 6.89 \\
Secondary teacher- economics & 6.37 & 5.61 \\
Secondary teacher- science & & \\
Female & 17.85 & 22.51 \\
Economist/financier & 13.08 & 10.64 \\
Nurse & 10.96 & 10.41 \\
Secondary teacher- humanities & 10.31 & 10.32 \\
Secondary teacher- economics & 10.31 & 8.33 \\
Secondary teacher- science & & \\
\hline
\end{tabular}

Comparing the PRR and SRR for various categories of teachers, both male economics and humanities teachers have a SRR greater than the PRR, as do female economics teachers. This suggests an under funding in these areas. If the methodologies in Model 2 and 3 are also applied, then for Model 2 the male economics teacher's SRR is 3.63 percentage points greater than their PRR and 2.65 percentage points greater in Model 3. For the female economics teacher, Model 2 shows that the SRR is 4.61 percentage points greater then their PRR and 2.24 percentage points higher in Model 3. These suggest considerable under funding in terms of the value to society of these graduates.

Similar comparisons could be made by comparing the rates of return of teachers with various qualifications and graduates with similar qualifications in the private sector. The results are likely to be similar in the fields that 
earn higher earnings than teachers. A comparison between nurses and a similar field is also likely to show that nursing students are under funded in higher education in Australia. Overall university education in Australia is under funded compared to other OECD nations. The Private Rates of Return are also much lower in comparison to the Social Rates of Return in most other OECD nations suggesting that Australian students have a lower incentive to pursue university qualifications and that the Government is providing a lower incentive and support for study. These results suggest that this could have considerable negative implications for productivity levels and future economic growth in the Australian economy.

\section{REFERENCES}

1. Ashenfelter, O. and Krueger, A. (1994). Estimates of the return to schooling from a new sample of twins. American Economic Review, vol. 84 no. 5 pp. 1157-1173.

2. Australian Bureau of Statistics (ABS). (2006). Household Expenditure Survey and Survey of Income and Housing- Confidentialised Unit Record Files, 2003-04. Cat. No. 6540.0.00.001 Canberra, Australian Bureau of Statistics.

3. Baum, S. and Payea, K. (2004). Education pays 2004. The benefits of higher education for individuals and society. Washington DC, College Entrance Examination Board. Viewed: $12^{\text {th }}$ February 2006, http://www.collegeboard.com/prod_downloads/press/cost04/EducationPays2004.pdf

4. Boal, W. and Ransom, M. (2000). Missouri Teachers. Unpublished paper, Brigham Young University.

5. Borland, J. (2002). New estimates of the private rate of return to university education in Australia. Melbourne, Department of Economics, University of Melbourne.

6. Borland, J. Dawkins, P. Johnson, D. and Williams, R. (2000). Returns to investment in higher education. Melbourne, Melbourne economics of higher education research program report No 1, University of Melbourne. Viewed: $20^{\text {th }}$ June 2005.

7. Correy, S. (2007). Background briefing. Testing the teachers. ABC radio national. Viewed: $2^{\text {nd }}$ March 2007, http://www.abc.net.au/rn/backgroundbriefing/stories/2007/1852400.htm

8. $\quad$ Cull, E. (2007). HECS caps do they work?. NTEU Advocate, vol. 14 no. 1 p.28.

9. Hirsch, B. and Schumacher, E. (1995). Monopsony Power and Relative Wages in the Labor Market for Nurses'. Journal of Health Economics, vol 14, no. 4. pp. 443-476.

10. Kaufman, B. E. and Hotchkiss, J. L. (2000). The economics of labour markets. Fort Worth, The Dryden Press, A division of Harcourt College Publishers.

11. McMahon, W. (2004). The social and external benefits of education in Johnes, G. and Johnes, J. International handbook of the economics of education. Surrey, Edward Elgar Publishing.

12. Marshall, A. (1890). Principles of economics. Marxists international archive. Viewed: $21^{\text {st }}$ February 2004, www.marxists.org/reference/subject/economics/marshall/bk4ch06.htm

13. McConnell, C. Brue, S. Macpherson, D. (2003). Contemporary labor economics. New York, McGraw-Hill Higher Education.

14. Mingat, A. and Tan, J. (1996). The full social returns to education: estimates based on countries' economic growth performance. Washington DC, World Bank.

15. Norris, K. (2000). Economics of Australian labour markets. Sydney, Pearson Education Australia.

16. Nowak, M. (2000). The nursing labour market in Western Australia: The story of a complex micro-labour market in a deregulating environment. Perth, Women's Economic Policy Analysis Unit, Curtin University of Technology. Discussion Paper No. 00-1.

17. Nowak, M. and Preston, A. (2000). 'Can human capital theory explain why nurses are so poorly paid'. Australian Economic Papers, vol. 40 no. 2 pp. 232-245.

18. Organisation for Economic Cooperation and Development (OECD). (2004) Education at a glance. OECD indicators: 2004. Paris, OECD. Viewed $16^{\text {th }}$ July 2005, http://www.oecd.org/edu/eag2004

19. Productivity Commission. (PC). (2007). Public support for science and innovation. Research report. Canberra, Productivity Commission. Viewed: $27^{\text {th }}$ March 2007, www.pc.gov.au/study/science/finalreport/index.html 
20. Psacharopoulos, G. (1975). Earnings and education in OECD countries. Paris, Organisation of Economic Cooperation and Development (OCED).

21. Psacharopoulos, G. and Pastrinos, H. (2002). Returns to investment in education: A further update. World Bank policy research working paper. 2881. Washington DC, World Bank.

22. Rizzo, M. (2005). The public interest in higher education. Cleveland, The Reserve Bank of Cleveland. Viewed: $11^{\text {th }}$ May 2006, http://www.clevelandfed.org/Research/EdConf2004/Nov/pdf/rizzo.pdf

23. Stokes, A. (2005). The influence of wages and nonwage amenities on the labour market for high school teachers in New South Wales. Sydney, Greenacre Educational Publications.

24. Topel, R. (2005). The private and social values of education. Cleveland, Federal Reserve Bank of Cleveland. Viewed: $10^{\text {th }}$ October 2006, http://www.clevelandfed.org/Research/EdConf2004/Nov/pdf/topel.pdf

25. Treasury. (2006). 2006-07 Budget Paper No. 1. Canberra, Commonwealth of Australia. Viewed: $10^{\text {th }}$ May 2007, http://www.budget.gov.au/2006-07/

26. Weisbrod, B. (1962). 'Education and investment in human capital'. The Journal of Political Economy, vol. 70 no. 5 pp. 106-123.

27. Zabalza, A. Turnbull, P. and Williams, G. (1979). The economics of teacher supply. London, Cambridge University Press.

\section{APPENDIX - METHODOLOGY FOR CALCULATING THE PRR AND SRR}

Estimates of rates of return are based on the Mincer equation (Mincer 1958). The specific rates of return in this study are calculated using Formula A.1 (Borland 2002 p.2).

$\mathrm{PV}_{\mathrm{C}}=\sum_{\mathrm{t}=1}^{\mathrm{n}} \mathrm{C}_{\mathrm{t}} /(1+\mathrm{r})^{\mathrm{t}}$

$\mathrm{PV}_{\mathrm{B}}=\sum_{\mathrm{t}=\mathrm{n}+1}^{\mathrm{m}} \mathrm{B}_{\mathrm{t}} /(1+\mathrm{r})^{\mathrm{t}}$

Then:

$\mathrm{PV}_{\mathrm{B}}-\mathrm{PV}_{\mathrm{C}}=0$ and solve for $\mathrm{r}$.

Where:

$C_{t}=$ opportunity costs for university degree in year $t$;

$\mathrm{B}_{\mathrm{t}}=$ benefit of university degree in year $\mathrm{t}$;

$\mathrm{n}=$ length of education;

$\mathrm{m}-\mathrm{n}=$ years in workforce; and

$\mathrm{r}=$ rate of return.

This study measures the income of a university student, a year 12 graduate and a university graduate based on ABS Household Expenditure Survey (HES) and Survey of Income and Housing (SIH) 2003-04 Confidentialised Unit Record Files (CURF) at person level. The study uses person level rather than income unit level data as it takes into consideration the participation in employment of the university graduates and year 12 leavers with no nonschool qualifications.

The ABS Household Expenditure Survey (HES) and Survey of Income and Housing (SIH) 2003-04 CURF contains a sample of dwellings surveyed throughout Australia from July 2003 to June 2004. The methodology 
basically follows that of Borland (2001) except that the sample used to obtain the estimates include male and female wage and salary earners age 18-60 years working part time and full time. Average earnings in the job with main employer are calculated for disaggregated age workforce groups- - 18, 19, 20, 21, 22, 23, 24, 25-29, 30-34, 35-39, 40-44, 45-49, 50-54 and 55, 56, 57, 58, 59, 60 years. It is assumed that age-earnings profiles derived using the 200304 HES and SIH CURF data apply over the future time period encompassed in this study. Real earnings growth for both high school and university graduates is assumed to be one percent per annum, the average increase in Australia in the previous 20 years.

\section{A1.1: Measuring The Costs Of Higher Education For A Student}

The first stage in measuring the costs of higher education is to measure the income a student forgoes while studying. The net forgone student income is equal to the difference between the income of a year 12 graduate and a university student. The opportunity cost of studying at university is the net forgone student income plus education costs including HECS fees and tuition costs. Table A.1 provides a summary of how this is calculated in this model.

Table A.1: A summary of the costs incurred while studying at university

\begin{tabular}{l}
\hline Forgone income \\
Income of a year 12 graduate minus \\
The income a student earns while studying (including employee earnings and income from scholarships and youth \\
allowance) \\
Education expenses \\
HECS plus \\
Tuition expenses \\
Total Expenses \\
Forgone income plus \\
Education expenses
\end{tabular}

\section{A.1.1.1: Income Of A Student}

The weekly earnings for both male and female full time university students for the ages 18 to 24 years were measured using Ordinary Least Squares (OLS) regression analysis. The formula used to calculate this is:

$\mathrm{Lw}_{\mathrm{t}}=\beta_{0}+\beta_{1} \mathrm{~A}+\beta_{2} \mathrm{~F}+\beta_{3} \mathrm{P} / \mathrm{T}+\beta_{4} \mathrm{E}+\beta_{5} \mathrm{~N}+\mu$

Where $\mathrm{Lw}=\log$ of earnings in year $\mathrm{t}, \beta_{0}=$ a constant term, $\mathrm{A}=$ age in years, $\mathrm{F}=$ dummy variable for female, $\mathrm{P} / \mathrm{T}=$ dummy variable for part time work, $\mathrm{E}=$ dummy variable for Country of Birth (English Speaking excluding Australia), $\mathrm{N}=$ dummy variable for Country of Birth (Non-English Speaking), and $\mu=$ error term

The regression equation does not include occupations or industries as the sample sizes available in the CURF for the classifications were too small. The base case in this model is that for a single male student who was born in Australia and works full time. In calculating the log of earnings for full time students, the student income is weighted according to the proportion of students who worked part time and not in paid employment. For those students who were not in paid employment their income was zero. The calculation of earnings for a full time student does not consider those students who study full time and work full time.

The weekly employee incomes of university students for the ages 18 to 24 years were then multiplied by 52 to give annual gross employee income ${ }^{3}$. The employee incomes of university students were then adjusted for real income growth of one percent per annum equal to the average annual change in real Average Weekly Earnings (AWE) for the years 1983 to 2005. This one percent real income growth is applied from the second year of study for 2004 and from the first year of study in 2005. This real adjusted annual employee income was then added to the

\footnotetext{
${ }^{3}$ The sample included the average earnings of people working over 52 weeks.
} 
income a student receives, from youth allowance and scholarships (based on the CURF sample) and then adjusted for tax (refer to Tables A.2 and A.3).

Table A.2: Individual income tax rates for 2003-04

\begin{tabular}{ll}
\hline Taxable income & Tax in this income \\
\hline$\$ 0-\$ 6000$ & Nil \\
$\$ 6001-\$ 21,600$ & 17 cents for each $\$ 1$ over $\$ 6000$ \\
$\$ 21,601-\$ 52,000$ & $\$ 2,652+30$ cents for each $\$ 1$ over $\$ 21,600$ \\
$\$ 52,001-\$ 62,500$ & $\$ 11,772+42$ cents for each $\$ 1$ over $\$ 52,000$ \\
$\$ 62,501$ and over & $\$ 16,182+47$ cents for each $\$ 1$ over $\$ 62,500$ \\
\hline Source: Adapted from ATO (2006) &
\end{tabular}

Table A.3: Individual income tax rates for 2004-05

\begin{tabular}{ll}
\hline Taxable income & Tax in this income \\
\hline$\$ 0-\$ 6000$ & Nil \\
$\$ 6001-\$ 21,600$ & 17 cents for each $\$ 1$ over $\$ 6000$ \\
$\$ 21,601-\$ 58,000$ & $\$ 2,652+30$ cents for each $\$ 1$ over $\$ 21,600$ \\
$\$ 58,001-\$ 70,000$ & $\$ 13,572+42$ cents for each $\$ 1$ over $\$ 58,000$ \\
$\$ 70,000$ and over & $\$ 18,612+47$ cents for each $\$ 1$ over $\$ 70,000$ \\
\hline
\end{tabular}

Source: Adapted from ATO (2006)

\section{A.1.1.2: The Income Of A Year 12 Graduate With No Post-School Qualifications For Ages 18-24 Years}

To calculate the forgone income of studying at university the differences between the student income and the earnings of a full time worker are measured. The student regression equation (as discussed earlier) is 4.1. The OLS regression equation for a male year 12 graduate with no post-school qualifications for the ages 18 to 24 years is equation A.3.

$\mathrm{Lw}_{\mathrm{t}}=\beta_{0}+\beta_{1} \mathrm{~A}+\beta_{2} \mathrm{~A}^{2}+\beta_{3} \mathrm{P} / \mathrm{T}+\beta_{4} \mathrm{E}+\beta_{5} \mathrm{~N}+\sum_{\mathrm{j}=1}^{9} \alpha_{\mathrm{j}} \mathrm{O}_{\mathrm{j}}+\sum_{\mathrm{j}=1}^{16} \theta_{\mathrm{j}} \mathrm{I}_{\mathrm{j}}+\sum_{\mathrm{j}=1}^{3} \pi_{\mathrm{j}} \mathrm{S}_{\mathrm{j}}+\mu$

Where $\mathrm{Lw}=\log$ of earnings in year $\mathrm{t}, \beta_{0}=$ a constant term, $\mathrm{A}=$ age in years, $\mathrm{A}^{2}=$ age squared in years, $\mathrm{P} / \mathrm{T}=$ dummy variable for part time work, $\mathrm{E}=$ dummy variable for Country of Birth (English Speaking excluding Australia), $\mathrm{N}=$ dummy variable for Country of Birth (Non-English Speaking), $\mathrm{O}=$ nine dummy variables for occupations, $\mathrm{I}=16$ dummy variables for industry, $\mathrm{S}=$ three dummy variables for income unit status and $\mu=$ error term

The base case is a single male without dependent children who is born in Australia. The person works full time as a professional in the industry category, property and business services.

Separate regression equations were also created for females for the ages 18-24 years. The only difference between the regression equations for males and females is for females the coefficient age cubed was included in the regression equation. For males the lifetime earnings profile forms a quadratic polynomial where in general income increases overtime, however, for females their lifetime earnings forms a cubic polynomial characterised by interruptions such as child rearing. The OLS regression equation (A.4) for a Female Year 12 graduate with no postschool qualifications for the ages 18 to 24 years is A.4. 
$\mathrm{Lw}_{\mathrm{t}}=\beta_{0}+\beta_{1} \mathrm{~A}+\beta_{2} \mathrm{~A}^{2}+\beta_{3} \mathrm{~A}^{3}+\beta_{4} \mathrm{P} / \mathrm{T}+\beta_{5} \mathrm{E}+\beta_{6} \mathrm{~N}+\sum_{\mathrm{j}=1}^{9} \alpha_{j} \mathrm{O}_{\mathrm{j}}+\sum_{\mathrm{j}=1}^{16} \theta_{\mathrm{j}} \mathrm{I}_{\mathrm{j}}+\sum_{\mathrm{j}=1}^{3} \pi_{\mathrm{j}} \mathrm{S}_{\mathrm{j}}+\mu$

Where $\mathrm{Lw}=\log$ of earnings in year $\mathrm{t}, \beta_{0}=$ a constant term, $\mathrm{A}=$ age in years, $\mathrm{A}^{2}=$ age squared in years, $\mathrm{A}^{3}=$ age cubed in years, $\mathrm{P} / \mathrm{T}=$ dummy variable for part time work, $\mathrm{E}=$ dummy variable for Country of Birth (English Speaking excluding Australia), $\mathrm{N}=$ dummy variable for Country of Birth (Non-English Speaking), $\mathrm{O}=$ nine dummy variables for occupations, $\mathrm{I}=16$ dummy variables for industry, $\mathrm{S}=$ three dummy variables for income unit status and $\mu=$ error term

The base case is a single female with no dependents who is born in Australia. The person works full time as a professional in the industry category, property and business services.

\section{A.1.1.3: Education Expenses}

As discussed in Chapter Three the opportunity cost of a university education consists of HECS, forgone income, books, tuition and extra travel. The Department of Education, Science and Training's student contribution tables for 2004 and 2005 are used to determine the level of HECS a student pays to study at university. This model calculates the return of a university degree for both students who pay their HECS fees upfront.

For the base case it is assumed that the student pays band two level of HECS upfront (with 25\% discount and $20 \%$ discount respectively) at $\$ 4025.25$ for 2004 and $\$ 5479.20$ for $2005^{4}$. It is also assumed that students in 2005 pay 25 percent higher HECS fees, as a result of the higher education policy changes (Table A.4).

Table A.4: Student contribution levels for Commonwealth Government Supported places for 2004 and 2005

\begin{tabular}{lcc}
\hline \multicolumn{1}{c}{ Student contribution band } & 2004 & $\begin{array}{c}\text { 2005 including 25\% higher } \\
\text { fees } \\
\text { indexed for 2005 }\end{array}$ \\
\hline Band 3 (law, dentistry, medicine, veterinary science) & $\$ 8018$ \\
$\begin{array}{l}\text { Band 2 (accounting, administration, economics, commerce, } \\
\text { mathematics, statistics, computing, built environment, health, } \\
\text { engineering, science, surveying, agriculture) }\end{array}$ & $\$ 6283$ & $\$ 6849$ \\
$\begin{array}{l}\text { Band 1 (humanities, behavioural science, social studies, foreign } \\
\text { languages, visual and performing arts) }\end{array}$ & $\$ 5367$ & $\$ 4808$ \\
National priorities (education, nursing) & $\$ 3768$ & $\$ 3847$ \\
Upfront discount & $\$ 3768$ & 20 percent
\end{tabular}

Source: Modified from AVCC (2006)

In measuring education expenses in both models the cost of books, tuition and extra travel are equal to Borland's (2002) estimation indexed to the CPI Tertiary Education Cost Index. The student outlay for books, tuition and extra travel for 2004 is $\$ 2289$ and for 2005 adjusted in real terms, $\$ 2360$. This is supported by University of New South Wales (2006) that estimates that the cost of textbooks are a minimum $\$ 500$ per year, the cost of field trips and equipment are approximately $\$ 1000$ per year, and the annual fee for university guilds and sports

\footnotetext{
${ }^{4}$ Borland (2002) also assumed students paid band two level of HECS.
} 
associations is $\$ 513.60$. In addition to these costs is the cost of parking for students at $\$ 8.00$ per day or $\$ 960$ per annum 5 .

\section{A.1.2: Private Rate Of Return}

According to Human Capital Theory, an individual's level of income is directly related to their level of education and experience. The Human Capital Model suggests that an individual with a university degree will receive a higher income over their lifetime compared to an individual who has only completed year 12 .

\section{A.1.2.1: Income Of A University Graduate And Year 12 Graduate With No Post-School Qualifications For The Ages 21 To 60 Years}

To estimate the log of earnings for both, a year 12 graduate and a university graduate for the ages 21 to 60 years, separate OLS regression equations were formed for males and females.

The OLS regression equation for a male including both university graduates and year 12 graduates with no post-school qualifications for the ages 21 to 60 years is equation A.5.

$\mathrm{Lw}_{\mathrm{tm}}=\beta_{0}+\beta_{1} \mathrm{~A}+\beta_{2} \mathrm{~A}^{2}+\beta_{3} \mathrm{~A}^{3}+\beta_{4} \mathrm{P} / \mathrm{T}+\beta_{5} \mathrm{~B}+\beta_{6} \mathrm{E}+\beta_{7} \mathrm{~N}+\sum_{\mathrm{j}=1}^{3} \tau_{\mathrm{j}} \mathrm{L}_{\mathrm{j}}+\sum_{\mathrm{j}=1}^{8} \alpha_{\mathrm{j}} \mathrm{O}_{\mathrm{j}}+\sum_{\mathrm{j}=1}^{16} \theta_{\mathrm{j}} \mathrm{I}_{\mathrm{j}}+\sum_{\mathrm{j}=1}^{3} \pi_{\mathrm{j}} \mathrm{S}_{\mathrm{j}}+$
$\sum^{11} \sigma_{\mathrm{j}} \mathrm{NS}_{\mathrm{j}}+\mu$

$j=1$

Where $\mathrm{Lw}=\log$ of earnings in year $\mathrm{t}, \beta_{0}=$ a constant term, $\mathrm{A}=$ age in years, $\mathrm{A}^{2}=$ age squared in years, $\mathrm{A}^{3}=$ age cubed in years, $\mathrm{P} / \mathrm{T}=$ dummy variable for part time work, $\mathrm{B}=$ dummy variable for left before year $12, \mathrm{E}=$ dummy variable for Country of Birth (English Speaking excluding Australia), N = dummy variable for Country of Birth (Non-English Speaking), L= three dummy variables for level of non-school qualification, $\mathrm{O}=$ eight dummy variables for occupations, $\mathrm{I}=16$ dummy variables for industry, $\mathrm{S}=$ three dummy variables for income unit status, $\mathrm{NS}=11$ dummy variables for non-school qualifications and $\mu=$ error term

The base case is for a sole person with no dependents who completed year 12 and is born in Australia. The person has a bachelor degree in management and commerce and works full time as a professional in the industry category, property and business services.

A separate equation was used to measure the income of female university graduates and year 12 graduates with no post-school qualifications for ages 21 to 60 years.

The OLS regression equation for female university graduates and year 12 graduates with no post-school qualifications for the ages 21 to 60 years is equation A.6.

$$
\begin{aligned}
& \mathrm{Lw}_{\mathrm{tf}}=\beta_{0}+\beta_{1} \mathrm{~A}+\beta_{2} \mathrm{~A}^{2}+\beta_{3} \mathrm{~A}^{3}+\beta_{4} \mathrm{P} / \mathrm{T}+\beta_{5} \mathrm{~B}+\beta_{6} \mathrm{E}+\beta_{7} \mathrm{~N}+\sum_{\mathrm{j}=1}^{3} \tau_{\mathrm{j}} \mathrm{L}_{\mathrm{j}}+\sum_{\mathrm{j}=1}^{8} \alpha_{\mathrm{j}} \mathrm{O}_{\mathrm{j}}+\sum_{\mathrm{j}=1}^{16} \theta_{\mathrm{j}} \mathrm{I}_{\mathrm{j}}+\sum_{\mathrm{j}=1}^{3} \pi_{\mathrm{j}} \mathrm{S}_{\mathrm{j}}+ \\
& \sum_{\mathrm{j}=1}^{11} \sigma_{\mathrm{j}} \mathrm{NS}_{\mathrm{j}}+\mu
\end{aligned}
$$

\footnotetext{
5 The annual figure for student parking assumes that the student attends university for four days per week, for 30 weeks in the year.
} 
The base case is for a sole person with no dependents who completed year 12 and is born in Australia. The person has a bachelor degree in management and commerce and works full time as a professional in the industry category, property and business services.

The earnings of both the year 12 graduate and the university graduate are then multiplied by 52 to give the annual gross employee earnings. The earnings are then adjusted for real income growth of one percent per annum. These earnings are then adjusted for employment probability. The unemployment rates for 2004 for a university graduate and year 12 graduate with no post-school qualifications are 3.0 percent and 6.56 percent respectively. This is based on the unemployment rate for those categories in 2004 (ABS, 2004). To allow for limitations of the Human Capital Model such as screening effects and innate ability the difference between a university graduate's income and year 12 graduate's income is multiplied by 80 percent (Ashenfelter and Krueger, 1994). The tax payable is calculated for each year using the ATO 2003-04 and 2004-05 income tax tables shown in Table A.2 and Table A.3.

A limitation of this model is that the income of a university graduate and year 12 graduate are based upon those workers who are earning paid incomes from full time and part time employment. It does not consider the income of workers who are self employed or not in the labor force.

\section{NOTES}


NOTES 